\title{
Kirjallisuutta
}

\section{Väestöntutkimuksen bibliografia 1960-1964}

\author{
Bibliography of Finnish Population Research, 1960-1964
}

Valtiot. kand. MARKETTA RITAMIES

Väestöpoliittinen Tutkimuslaitos

Yhteiskuntatieteiden maisteri Helmi Nykänen († 1959) on esittänyt Väestöliiton Vuosikirjoissa II-IV luetteloita väestökysymystä, perhettä ja avioliittoa käsittelevästä suomalaisesta kirjallisuudesta vuosina 1941-1952. Näiden jatkona on ilmestynyt valtiotieteen lisensiaatti Aarno Strömmerin kokoama suomalaista väestöntutkimusta vuosina 1953-1959 esittelevä bibliografia, joka julkaistiin Väestöntutkimuksen Vuosikirjassa VI. Seuraavassa esitettävä bibliografia, joka käsittelee väestöntutkimuksen alalla vuosina 1960-1964 ilmestynyttä suomalaista kirjallisuutta, on jatkoa näille luetteloille.

Bibliografia sisältää kuten aikaisemmin- kin Suomessa painettujen itsenäisten julkaisujen lisäksi myös täällä ilmestyneiden aikakauslehtien ja kokoomateosten kirjoituksia. Sanomalehtien artikkeleita ei siihen sisälly. Luetteloon on otettu mukaan myös ulkomailla ilmestyneitä Suomea koskevia kirjoituksia.

Aineiston luokittelussa on noudatettu Princetonin yliopiston ja Amerikan väestöntutkijain yhdistyksen julkaiseman Population Index -aikakauslehden käyttämää jaottelua. Alaryhmien kohdalla siitä on jonkinverran poikettu. Siten on luettelo saatu paremmin omia tarpeitamme vastaavaksi.

\section{A. YLEINEN VÄESTÖN- TUTKIMUS JA TEORIA}

General population studies and theory

1. Forsberg, Karl-Erik. Demografisen kehityksen nykytilanne Pohjoismaissa. Väestöntutkimuksen Vuosikirja VI, s. 126 -132. Vammala 1960.

2. Fougstedt, Gunnar. Väestötiede. Yhteiskuntatieteiden käsikirja II, s. 997-1000. Keuruu 1964.
3. Kiiskinen, Auvo. Ekologia. Yhteiskuntatieteiden käsikirja I, s. 99-104. Keuruu 1963.

4. Lautkari, Heikki. Eräs stabiilin väestön ja Eilert Sundtin lain matemaattinen tulkinta. (Summary: A Mathematical Interpretation of the Concept of the Stable Population and Eilert Sundt's Law.) Väestöntutkimuksen Vuosikirja VII, s. 58-74. Vammala 1962.

5. Lento, Reino. Väestö. Yhteiskuntatieteiden käsikirja II, s. 977-982. Keuruu 1964. (Eripainos: Turun yliopisto. Taloustieteen laitos. Tutkielmia 4.) 
6. Monikielinen väestötieteen sanakirja. Suomenkielinen laitos. (Multilingual demographic dictionary. Finnish section.) Toimituskunta G. Fougstedt, J. Hyppölä, T. Purola ja A. Strömmer. Suomen Tilastoseuran Julkaisuja 1, Helsinki 1962. 148 s.

7. Strömmer, Aarno. Väestönmuutokset. Yhteiskuntatieteiden käsikirja II, s. 982989. Keuruu 1964.

8. Väestöntutkimuksen Vuosikirja VI. Vammala 1960, 190 s. - VII. Vammala 1962, 182 s. - VIII. Vammala 1964, 155 s.

\section{B. OSA-ALUEIHIN KOHDISTU- VAT (YLEISET) VÄESTÖN- TUTKIMUKSET}

\section{Regional population studies}

9. Allardt, Erik. Files for aggregate data by territorial units in Finland. Helsingin yliopiston sosiologian laitoksen tutkimuksia N:o 42. Helsinki 1964. $7 \mathrm{~s}$.

10. Allardt, Erik. Implications of intracountry variations and regional imbalances for cross-national research. Helsingin yliopiston sosiologian laitoksen tutkimuksia N:o 25. Helsinki 1963. 11 s.

11. Allardt, Erik. Kuntien faktoripistemäärät Etelä- ja Länsi-Suomen maalaiskuntien faktoreissa. Helsingin yliopiston sosiologian laitoksen tutkimuksia N:o 34 . Helsinki 1963. 11 s.

12. Elfvengren, Elisabeth. Demografisia tietoja Helsingin kaupungin väestöstä v:n 1960 väestölaskennan mukaan. Demografiska uppgifter om Helsingfors stads befolkning enligt 1960 års folkräkning. (Summary: Demographic data on the population of Helsinki according to the 1960 census.) Tilastollisia kuukausitietoja Helsingistä 1963, 11, 357-394.

13. Elfvengren, Elisabeth. Ennakkotietoja Helsingin seudun väestöstä vuoden 1960 väestölaskennan mukaan. Förhandsuppgifter om befolkningen i Helsingforsregionen enligt 1960 års folkräkning. (Summary: The population of the Helsinki region, 1960.) Tilastollisia kuukausitietoja Helsingistä 1963, 3, 53-83.
14. Forsberg, K-E, F. Gustafsson, S. Hyvärinen, A. Saxén ja A. Strömmer. Helsingin seudun väestöllisestä kehityksestä ja siihen liittyvistä ongelmista. (Population trends in the Helsinki region and problems related to them.) Valtakunnansuunnittelutoimiston julkaisusarja A: 13 . Helsinki $1963,170 \mathrm{~s}$.

15. Forsberg, K-E, F. Gustafsson, S. Hyvärinen, $\AA$. Saxén ja A. Strömmer. Helsingin seudun väestöllisestä kehityksestä ja siihen liittyvistä ongelmista. Befolkningsutvecklingen i Helsingforsregionen och därmed sammanhängande problem. Valtakunnansuunnittelutoimiston julkaisusarja B: 5. Helsinki 1963, 199 s.

16. Hakulinen, Kerkko. Ranskan väestö. Suomalainen Suomi 1964, 1, 31-35.

17. Hartman, T. ja P. Puumalainen. Väkiluvun muutoksista maaseudulla. S. 5566 teoksessa: Muuttuva maaseutu. Toim. Kyösti Skyttä. Opintotoiminnan Keskusliiton julkaisuja N:o 7, Helsinki 1962.

18. Helle, R. Turun saariston väestönkehitys 1910-1959. Turun ylioppilas 8. s. 164-192. Forssa 1961.

19. Hertzen, Heikki von. Uusimaa vv. 1965-2000. Yhdyskuntasuunnittelumme ainutkertainen mahdollisuus. Asuntopolitiikka 1964, 3, 4-7. (Myös Lakimies ja Yhteiskunta-lehdessä 1964.)

20. Hyvärinen, Salme. Eräiden Helsingin lähiseudun yhdyskuntien rakenne ja niihin suuntautuvan muuttoliikkeen syyt. S. 83-113 teoksessa: Forsberg, K-E. ym. Helsingin seudun väestöllisestä kehityksestä ja siihen liittyvistä ongelmista. Valtakunnansuunnittelutoimiston julkaisusarja A: 13. Helsinki 1963.

21. Jaatinen, Stig. Mariehamns befolkning. (The population of Mariehamn.) Ålandsfolkminnesförbund. Åländsk odling 23, årsbok 1962, s. 3-41. Mariehamn 1962.

22. Jaatinen, Stig. Saaristo-Suomen väestö ja sen elinkeinot. Mercurialia 1961, s. 185-202, Helsinki 1961.

23. Kymenlaakson väestö ja työvoima sekä laskelmia niiden kehityksestä vuoteen 1970. Kymenlaakson seutukaavayhdistys. Sarja A. 1. Kotka 1962. 50 s.

24. Pipping, Knut. Lounaisen ulkosaaristomme väestönkehitys. (Summary: Population Development of the Outer 
Archipelago in SW Finland.) Väestöntutkimuksen Vuosikirja VIII, s. 22-35. Vammala 1964.

25. Purola, Tapani. Lisälaskelmia Kymenlaakson väestöstä ja työvoimasta sekä niiden kehityksestä vuoteen 1980 . Kymenlaakson seutukaavayhdistys. Sarja A.2. s. $51-65$, Kotka 1962.

26. Purola, Tapani ja Antti Tuura. Salon vaikutusalueen väestö ja työvoima sekä laskelmia niiden kehityksestä. Salon seudun aluesuunnitteluyhdistyksen julkaisuja 10. 1. Vihti $1960.64 \mathrm{~s}$.

27. Saarikivi, Hertta. Littoisten väestökeskus ja Turun vaikutus sen asukkaisiin. Turun ylioppilas 10. s. 83-91, Forssa 1963.

28. Savonen, M. Suomen eri alueiden väkilukujen kehitys 1950-luvulla. Teollisuuslehti 1962, 1, 10-12.

29. Siirilä, S. Seinäjoen väestö. Kytösavut 9. s. 61-78. Seinäjoki 1962.

30. Strömmer, Aarno. Tampereen väestön kehitys vuosina 1950-1990. Tutkimus väkiluvun ja väestörakenteen muutoksista Tampereella 1950-luvun kuluessa sekä tähän tutkimukseen perustuva ennuste kehityksestä vuoteen 1990. Tampere 1963. $40 \mathrm{~s}$.

31. Tuura, Antti. Jyväskylän väestönkehitys. Jyväskylä 1964, $38 \mathrm{~s}$.

32. Tuura, Antti. Muutoksia PohjoisSavon väestöoloissa ja kunnallistaloudessa 1950-luvulla. Maalaiskunta 1963, 9, 358 -362 .

33. Tuura, Antti. Väestön kasvusuunnasta maamme eri talousalueilla - arviointia kauden 1951-1955 kehityksen perusteella. Väestöntutkimuksen Vuosikirja VI, s. 113-119. Vammala 1960.

34. Wirilander, Kaarlo. Savon väestöoloja $1721-1870$. Turku 1964. 78 s. (Eripainos: Historiallinen arkisto 59.)

\section{ALUEELLINEN JAKAANTU- MINEN \\ Spatial distribution}

35. Ajo, Reino. Rovaniemen allas väkiluvun keskimääräisen vuosikasvun maantieteellisen vaihtelun ilmentämänä ja al- taan muuttoliikkeen olosuhteissa 18661939. (Summary: The Rovaniemi Basin as shown by the geographical variations in the average annual growth of population, and the time variation in the net migrational rate for the basin in the light of economic fluctuations and in conditions of unrestricted migration, 18661939.) Terra 1962, 74 (1), 8-22.

36. Elfvengren, Elisabeth. Kaupungin keskipiste. Stadens medelpunkt. (Summary: The central point of the city). Tilastollisia kuukausitietoja Helsingistä 1964, 1, 64-72.

37. Elfvengren, Elisabeth. Pääkaupungin väestö kaupunginosittain asuin- ja työpaikan mukaan vuonna 1960. Huvudstadens befolkning stadsdelsvis enligt boplats och arbetsplats år 1960. (Summary: The population of Helsinki according to place of residence and place of work, by city ward in 1960.) Tilastollisia kuukausitietoja Helsingistä 1963, 7, 193-232.

38. Fogelberg, Paul. Finlands tätorter 1960. (Summary: The Urban Settlements of Finland 1960.) Terra 1963, 3, 257-268.

39. Forsberg, Karl-Erik. Kaupunkimaistuminen 1950-luvulla voimakasta - taajamissa asui v. 1960 noin $60 \%$ väestöstä. Suomen Kunnallislehti 1964, 1, 38-39.

40. Hartman, Tor. Alueellinen väestöennuste vuoteen 1990 saakka. Regional befolkningsprognos till år 1990. (Regional population projection to the year 1990.) Tilastokatsauksia 1963, 10, 45-49.

41. Hartman, Tor. Alueellinen väestöja ruokakuntaennuste vuoteen 1990 saakka. Regional prognos över befolkning och hushåll till år 1990. (Regional projection of population and households to the year 1990.) Tilastollisia tiedonantoja 41. Helsinki 1964, $46 \mathrm{~s}$.

42. Hartman, Tor. Alueittainen ennuste ammatissa toimivasta väestöstä vuoteen 1975 saakka. Regional prognos av yrkesverksamma till år 1975. (Summary: Regional projection of economically active population to the year 1975.) Tilastokatsauksia 1964, 3, 46-51.

43. Heinilä, Kalevi. Yhteiskunnan kaupungistuminen. (Summary: Aspects of Urbanization.) Väestöntutkimuksen Vuosikirja VIII, s. 19-33. Vammala 1962. 
44. Hult, Juhani. Der Einfluss der Zentren auf die Bevölkerungsdichte ihrer Verkehrsgebiete. Fennia 87. s. 1-49, Helsinki 1963.

45. Immonen, E. J. Asutuksen taajamaluontoisuus. Maalaiskunta 1963, 3, 103 -105 .

46. Jutikkala, Eino. Suomen kaupunkien synty ja kehitys. Oma maa X. s. 403-417. Porvoo 1961.

47. Palmgren, Kai. Alueellisista kehittyneisyyseroista maassamme. Maalaiskunta $1964,8,334-340$.

48. Palmgren, Kai. Kehittyneisyyden alueittaisista eroavuuksista Suomessa. (Summary: Regional Differences in the Degree of Development in Finland.) Valtakunnansuunnittelutoimiston julkaisusarja A: 15. Helsinki $1964.160 \mathrm{~s}$.

49. Piepponen, Paavo. Suomen kuntien sosiaalisen rakenteen perustekijät. (Summary: Dimensions of Ecological Differentiation in Finnish Communes.) Väestöntutkimuksen Vuosikirja VII, s. 34-46. Vammala 1962.

\section{VÄKILUVUN KEHITYS}

Trends in population size

50. Ajo, Reino. On the field profile of the rate of total increase of population as exemplified by Tampere, Finland. Fennia 86. 3. s. $1-21$. Helsinki 1962.

51. Arvioidut väkiluvut 1.1.1964 (Estimated population on January 1, 1964.) Tilastokatsauksia 1964, 1, 57-58.

52. Forsberg, Karl-Erik. Näkökohtia Helsingin seudun tulevasta väestönkehityksestä ja yhdyskuntasuunnittelusta. S. 65-82 teoksessa: Forsberg, K-E. ym. Helsingin seudun väestöllisestä kehityksestä ja siihen liittyvistä ongelmista. Valtakunnansuunnittelutoimiston julkaisusarja A: 13 . Helsinki 1963.

53. Forsberg, Karl-Erik. Yleisluonteinen katsaus väestönkehityksen aiheuttamiin yhteiskunnallisiin ongelmiin. S. 9-18 teoksessa: Forsberg, K-E. ym. Helsingin seudun väestöllisestä kehityksestä ja siihen liittyvistä ongelmista. Valtakunnan- suunnittelutoimiston julkaisusarja A: 13 . Helsinki 1963.

54. Fougstedt, Gunnar. Några utvecklingstendenser för befolkning och arbetskraft. S. 13-52 teoksessa: Finlands samhällsekonomi inför morgondagens Europa. Festskrift. Ekonomiska Samfundet i Finland 1894-1964. Toim. Gösta Mickwitz. Helsingfors 1964, 274 s.

55. Hartman, Tor. Vuoden 1959 väestöennusteen oikaisu vuoden 1960 väestönlaskennan perusteella. Korrigering av 1959 års befolkningsprognos på basen av 1960 års folkräkning. (The 1959 population prognosis corrected on the basis of the 1960 population census.) Tilastokatsauksia 1963, 1, 56-59.

56. Jutikkala, Eino. Suomen väkiluvun kasvaminen. Oma maa VII. s. 197209. Porvoo 1960.

57. Laskelmia väestönkehityksestä Suomen kunnissa vuosina 1960-1990. Framräkningar rörande befolkningsutvecklingen i Finlands kommuner åren 1960-1990. (Calculations concerning the population development in the communes of Finland during 1960-1990.) Valtakunnansuunnittelutoimiston julkaisusarja A:16. Helsinki 1964. $126 \mathrm{~s}$.

58. Lento, Reino. Maailman väestönkasvu ja kansainväliset suhteet. Suomalainen Suomi 1962, 7, 398-405.

59. Lento, Reino. Varsinais-Suomen väestönkehitys 1960-luvulla. Talousvaaka 1962, 1, 9-11.

60. Mazumdar, Jyoti ja Aarno Strömmer. Väestönkehityksestä ja väestöpolitiikasta Intiassa. (Summary: Population Development and Population Policy in India.) Väestöntutkimuksen Vuosikirja VII, s. 9-18. Vammala 1962.

61. Piepponen, Paavo. Maamme viimeaikaisesta väestönkehityksestä. Väestöntutkimuksen Vuosikirja VIII, s. 105-113. Vammala 1964.

62. Piepponen, Paavo. Väestöennuste vuoteen 1990 - haaste valtakunnansuunnittelulle. Valtakunnansuunnittelu 1964, 3,6 .

63. Purola, Tapani. Väestön- ja työvoimankasvun kehityssuunnista maamme eri talousalueilla vv. 1950-70. Maalaiskunta 1960, 6, 270—274. 
64. Raivio, Arvi. Uusi väestöprognoosi ennakoi voimakasta väestönkasvua kaupungeissa ja kauppaloissa. Suomen Kunnallislehti 1964, 1, 42-43.

65. Raivio, Arvi. Väkilukumme ja eri ikäryhmien muutoksista vuoteen 1990. Huoltaja 1964, 8, 239-244.

66. Saxén, Åke ja Aarno Strömmer. Helsingin ja sen lähiympäristön väestönkehitys vuosina $1900-1960$. S. 29-64 teoksessa: Forsberg, K-E. ym. Helsingin seudun väestöllisestä kehityksestä ja siihen liittyvistä ongelmista. Valtakunnansuunnittelutoimiston julkaisusarja A: 13 . Helsinki 1963.

67. Siipi, Jouko. Väestönkehityksen huomioon ottaminen sosiaalihuollon suunnittelussa. Huoltaja 1961, 10, 309-310, 313-316.

68. Strömmer, Aarno. Maapallon väestöpulma - ihmiskunnan lisääntymisen näköalat YK:n uusien laskelmien valossa. Väestöntutkimuksen Vuosikirja VI, s. 133 -138. Vammala 1960.

69. Strömmer, Aarno. Selvitys väestönkasvun alueittaisista eroista Suomessa kaudella 1951-1955. (A report on regional difference in the growth of the population of Finland during the period 1951-1955.) Valtakunnansuunnittelutoimiston julkaisusarja A: 1. Helsinki 1960. 50.

70. Strömmer, Aarno. Suomen väestönkehityksen nykyvaihe. Suomen Silta 1962, 2, 14-15.

71. Tuura, Antti. Väestömme kasvu ja sen rakennemuutoksen suunta. Sosiaalityö 1963, 1, 5-7.

72. Tuura, Antti. Väestönkehitys ja sen muutostekijät. Maalaiskunta 1962, 20, 937-940.

73. Tuura, Antti ja Tapani Purola. Väestön ja työvoiman kasvu Suomessa vuoteen 1970. (Summary: The growth of population and labor force in Finland to 1970.) Väestöpoliittisen Tutkimuslaitoksen Julkaisuja, Sarja A: 11. Vammala 1961. $100 \mathrm{~s}$.

74. Vartiovaara, K. Väestön kasvu ja muuttoliike vuoteen 1990 mennessä. Tatalouselämä 1964, 44, 1012-1014, 1028.

\section{E. KUOLEVUUS}

\section{Mortality}

\section{Yleinen - General}

75. Hartman, Tor. Kuolleisuus ja keskiikä. Oma maa XI. s. 359-362. Porvoo 1962.

76. Immonen, Erkki. Tapaturma, tauti, tuonela. Huoltaja 1960, 48, 388-392, 394396.

77. Saxén, Ake. Kuolleisuus ja elinaika Helsingissä. Dödlighet och livslängd i Helsingfors. (Summary: Mortality and length of life in Helsinki.) Tilastollisia kuukausitietoja Helsingistä 1964, 3, 85-103.

78. Varpela, Erkki. Kokonaiskuolleisuudesta kaupunkiin suuntautuvan muuttoliikkeen yhteydessä. Sosiaalilääketieteellinen Aikakauslehti 1964, 5, 21-29.

\section{Imeväiskuolevuus - Infant mortality}

79. Ahvenainen, E. K. ja M. Kunnas. Mortality of premature infants by distance of transportation, place of delivery and urban versus rural origin. Annales Paediatrie Fenniae 1963, 9, 97-112.

80. Bardy, Anja ja Kyllikki Kauttu. Perinataalikuolleisuuteen liittyvistä tekijöistä Uudellamaalla. Kätilölehti 1961, 11, 506-513.

81. Hallman, N. ja P. Louhivuori. Infant mortality in Finland. Dia Medico (Buenos Aires) 1960, 32, 1864-1868.

82. Kasanen, Antero ja Lauri Rauramo. Raskauden aikaisen virtsainfektion merkitys perinataaliseen mortaliteettiin ja keskosuusfrekvenssiin. Avioliitto ja Lääkäri 1963, 4, 94-96.

83. Miemois, K. Spädbarndödligheten och dödligheten i tuberkulos i Närpes 1749-1961. Suomen Lääkärilehti 1962, 27, 2117-2121.

84. Räihä, C. E. The possibilities of reducing perinatal mortality. Annales Paediatriae Fenniae 1963, 9, 152-167.

85. Saarimaa, Arja. Maamme imeväiskuolleisuus vuosina 1951-1960. Duodecim 1962, 10, 499-501. 
86. Takala, M. E. ja L. Laakso. Perinataalisesta kuolleisuudesta aluesairaalassa. Duodecim 1964, 12, 557-564.

\section{Muiden ikävuosien kuolevuus - Mortality at other ages}

87. Geron, Vuosikirja XII - XIII. 1960-1961. Societas Gerontologica Fennica. Helsinki 1962. 125 s.

- XIV - XV. 1962-1963. 1963. 145 s.

- XVI. 1964. 1964. 87 s.

88. Jalavisto, Eeva. Kuolevuuden sukupuolihakuisuudesta aikuisiässä. Geron XVI. s. 47-57. Helsinki 1964.

89. Järvinen, Erkki. Missä määrin kuolema tapahtuu työiässä. Työterveysuutiset 1963, 2, 6-7.

90. Järvinen, Erkki. Vertailevaa tarkastelua työikäisten kuolleisuudesta. A. Vanhentumisilmiö kuolleisuuden valossa. Työterveysuutiset 1963, 3, 6 .

\section{Kuolemansyyt - Mortality by cause}

91. Achté, K. A. Itsemurhat ja itsemurhayritykset. (Suicides and Attempted Suicides.) Sosiaalilääketieteellinen Aikakauslehti 1963, 2, 21-28.

92. Achté, K. A. Sosiaalinen tutkimus Helsingissä 1958-1960 tehdyistä itsemurhista. (Summary: A social study of the suicides committed in Helsinki in 19581960.) Duodecim 1962, 14, 677-682.

93. Antikainen, Iris. Kuolemansyyt vuonna 1959. Dödsorsakerna år 1960. (Summary: Causes of death in 1959.) Tilastokatsauksia 1960, 35(8), 44-47.

- 1960. 1961, 10, 49-52.

94. Apo, M., L. Haapaniemi ja K. A. Achté. Itsemurhat Suomessa 1954-1958. (Suicides in Finland during 1954-1958.) Sosiaalilääketieteellinen Aikakauslehti 1963, 4, 17-25.

95. Bruun, K., E. Koura, R. E. Popham ja J. R. Seeley. Maksakirroosikuolleisuus alkoholismin levinneisyyden mittarina. Väkijuomakysymyksen tutkimussäätiö. Julkaisuja 8. 2. Helsinki 1960. 115 s.

96. Hakama, M. ja E. Saxén. Keuhkosyöpäkuolleisuuden nousuun vaikuttavista tekijöistä. Duodecim 1964, 18, 781-785.
97. Immonen, Erkki. Alkoholismiin kuolleisuus Suomessa. Alkoholipolitiikka 1964, 3, 165-166. - Alkoholism som dödsorsak i Finland. Alkoholpolitik 1964, 3, 144-145.

98. Isotalo, Antti. Medico-legal aspects of medical certification of cause of death. Bulletin of the World Healt Organisation 1960, 23(6), 811-814. (Myös Acta Medicinae Legalis et Socialis-lehdessä 1963.)

99. Jokipii, S. G. ja A. E. Heino. The causes of death in persons over 90 in the light of autopsy material. Annales Medicinae Internae Fenniae 1963. Vol. 52 Supplementum 40. 11-21.

100. Järvinen, Erkki. Vertailevaa tarkastelua työikäisten kuolleisuudesta. Tärkeimmät kuolemansyyt eri maissa. Työterveysuutiset 1964, 2, 12-13.

101. Klemetti, Lahja. Keuhkosyöpäkuolleisuudesta maassamme. Suomen Lääkärilehti 1961, 33, 1971-1978.

102. Korpela, Aino. Syöpäkuolleisuudesta ja syövän esiintymisestä Suomessa. (Summary: On Cancer Mortality and Incidence in Finland.) Väestöntutkimuksen Vuosikirja VII, s. 47-57. Vammala 1962.

103. Krokfors, Gunvor ja Erik Krokfors. Naisten kuolleisuuden synnyttäneisyyden mukaisesta jakautumisesta. Avioliitto ja Lääkäri 1961, 3, 86-89.

104. Mattila, Antti. Sydämen ja verisuoniston tautien eräissä maissa vuonna 1957 aiheuttamasta kuolleisuudesta. (Summary: On mortality due to cardiac and vascular diseases in certain countries in the year 1957.) Duodecim 1961, 20, 731-744.

105. Saarimaa, Heikki ja Arja Saarimaa. Itsemurhista Helsingissä, Turussa ja Tampereella vuosina 1946-1960. (On Suicides commited in Helsinki, Turku and Tampere during the Years 1946-60.) Sosiaalilääketieteellinen Aikakauslehti 1962, näytenumero, 19-23.

106. Ylppö, Arvo. Sosiaalilääketieteellisten ja erinäisten ympäristötekijäin vaikutuksesta lasten yleiseen kehitykseen ja kuolleisuuteen. Sosiaalilääketieteellinen Aikakauslehti 1964, 2, 1-3. 


\section{F. SYNTYVYYS JA LUONNOL-} LINEN LISÄANTYMINEN

Fertility and natural increase

Yleinen - General

107. Hartman, Tor ja Pentti Puumalainen. Aviollisen hedelmällisyyden vaihteluista Suomessa. (Summary: On the Variation of Marital Fertility in Finland.) Väestöntutkimuksen Vuosikirja VI, s. 6083. Vammala 1960.

108. Kahanpää, K, H. Väestönmuutokset vuonna 1959. Befolkningsrörelsen år 1959. (Vital statistics in 1959.)

Tilastokatsauksia 1960, 8, 40-43.

- 1960. 1961, 10, 45- 48.

- 1961. 1962, 11, $44-48$.

- 1962. 1963, 12, 45- 47 .

- 1963. 1964, 10, 58-59.

109. Krokfors, Erik. Synnyttäneisyysjakautuman vaihteluista eri puolilla maatamme v. 1955. (Summary: Regional variations in parity rate in 1955.) Duodecim 1961, 77, 66-70.

110. Nieminen, Armas. Esiaviollisten raskauksien yleisyydestä Suomessa. Sosiologia 1964, 1, 14-18.

111. Nieminen, Armas. Premarital Pregnancy in Finland. Acta Sociologica 1964, 4, 225-228.

112. Nieminen, Usko. ABO blood groups and female fertility. Duodecim 1959, 75, 942-947.

113. Renkonen, $K$. O. et al. The time interval from the wedding to the birth of the first child. Annales Medicinae Experimentalis et Biologiae Fenniae 1963, 41, $560-564$.

114. Visuri, Elina. Suomalaisten synnyttäjien raskausetäisyyksistä. (Summary: Inter-pregnancy Intervals of Finnish Women.) Väestöntutkimuksen Vuosikirja VIII, s. 36-64. Vammala 1964.

\section{Syntyvyyden säännöstely - Fertility controls}

115. Järvinen. P. A., C-J. Johansson, V. Kannisto ja S. Timonen. Incidence and causes of childlessness in marriage. Annales Chirurgiae et Cynaecologiae Fenniae 1962, 51, 91-100.
116. Järvinen, P. A., C-J. Johansson, V. Kannisto ja S. Timonen. Tahallisen ja tahattoman lapsettomuuden esiintymisestä Helsingissä. Avioliitto ja Lääkäri 1961, 2, 43-46.

117. Kauraniemi, Tapani. Perhesuunnittelu USA:ssa. Avioliitto ja Lääkäri 1960, 1, 13-19.

118. Nieminen, Usko. Viisivuotinen kokeilu perhesuunnittelusta eräällä hiilikaivosalueella Japanissa. Avioliitto ja Lääkäri 1962, 2, 39-42.

119. Stolte Heiskanen, Veronica. The current status of family planning publications: a cross-cultural content analysis. Helsingin yliopiston sosiologian laitoksen tutkimuksia 31. Helsinki 1963. $20 \mathrm{~s}$.

120. Viinisalo, Päivikki. Eräitä ajatuksia avioliittoneuvonnasta. 9.4.1961 pidetty esitelmä. Avioliitto ja Lääkäri 1961, 3, 91-98.

121. Viinisalo, Päivikki. Kokemuksia avioliittoneuvontatyöstä Yhdysvalloissa. Avioliitto ja Lääkäri 1960, 4, 140-143.

122. Viinisalo, Päivikki. Perhe- ja avioliittoneuvonta. Suomen Kätilöliiton luentopäivillä 19.3.1960 pidetty esitelmä. Kätilölehti $1960,9,360-365$.

\section{G. AVIOLIITTO, AVIOERO JA PERHE}

Marriage, divorce, and the family

123. Eskola, Antti. Aviopuolisoiden roolijakoon vaikuttavat tekijät. (Summary: Some Factors Influencing the Differentiation of the Roles of Spouses.) Väestöntutkimuksen Vuosikirja VI, s. 8498. Vammala 1960.

124. Haavio-Mannila, Elina. Perhe. Yhteiskuntatieteiden käsikirja I, s. 468472. Keuruu 1963.

125. Haavio-Mannila, Elina. Perheenjäsenten asema ja roolit entisajan suurperheessä. Lapsi ja Nuoriso 1960, 4, 122125.

126. Heinilä, Kalevi. Perhekumppanuus ja perheen kiinteys. (Summary: Family Companionship and Family Cohesion.) Väestöntutkimuksen Vuosikirja VII, s. 75-100. Vammala 1962. 
127. Immonen, Erkki. Perhe-elämän rappeutuminen ja avioerot. Sarjassa -Yksilö, perhe ja alkoholi». Huoltaja $1960,58,32-38$.

128. Joensuu, Matti. Havaintoja perheneuvonnasta ja eri ammattikuntien yhteistyöstä USA:ssa. Avioliitto ja Lääkäri 1960, 4, 136-137, 152.

129. Lanu, K. E. Perhe muuttuvassa yhteiskunnassa. Sairaanhoitajalehti 1963, 3, 100, 102, 126.

130. Lumio, Jaakko S. ja Pertti Paljakka. Tutkimuksia Suomen kuurojen keskisistä avioliitoista. Helsinki 1964. 15 s. (Eripainos: Duodecim 1964, 43.)

131. Nieminen, Armas. Avioliitto. Yhteiskuntatieteiden käsikirja I, s. 7886. Keuruu 1963.

132. Nieminen, Armas. Perhe ja muuttuva yhteiskunta. Teollistuva yhteiskunta. Yhteiskunnallisen Korkeakoulun Vuosikirja VI. s. 27-37. Tampere 1962.

133. Nieminen, Armas. Perhesosiologia. Yhteiskuntatieteiden käsikirja I, s. 478480. Keuruu 1963.

134. Nimkoff, M. F. Perhemuotojen kehitys maailmassa. Avioliitto ja Lääkäri 1960, 3, 107-110.

135. Perheet perhetyypin mukaan lääneittäin 31.12.1960. Tilastokatsauksia 1963, $2,45-46$.

136. Piepponen, Paavo. Early marriage in Finland, 1878-1960. Väestöpoliittisen Tutkimuslaitoksen julkaisuja, sarja B: 1 . Helsinki 1964. 14 s.

137. Piepponen, Paavo. Nuorten avioliitot. Avioliitto ja Lääkäri 1964, 3, 6065. (Myös Lakimies ja Yhteiskunta -lehdessä 1964 ja Lapsi ja Nuoriso -lehdessä 1964.)

138. Piha, Kalevi. Suurperhe karjalaisessa työyhteisössä. Karjalainen suurperhe sosiaaliantropologian ja sosiaalipsykologian valossa. Turun yliopiston sosiologian laitos. Sarja B: 6. Turku 1964. $137 \mathrm{~s}$.

139. Puumalainen, Pentti. Avioero. Yhteiskuntatieteiden käsikirja I, s. 7578. Keuruu 1963.

140. Raitasuo, K. Lapsi ja eroavat vanhemmat. Lastensuojelun keskusliiton julkaisuja 22. Helsinki 1963. 33 s.
141. Raivio, Arvi. Avioerot lisääntyvät. Huoltaja 1964, 3, 69-70, 73.

142. Raivio, Arvi. Avioerot vuosina 1959-1960. Skilsmässorna åren 19591960. (Divorces in 1959 and 1960.) Tilastokatsauksia 1961, 11, 45-47.

- 1961-1962. 1963, 10, 50-52.

143. Saramo, Kai. Erisuuruisten ruokakuntien kulutustaso Engelin käyrien avulla mitattuna. (Summary: The Consumption Level of Finnish Households of Different Sizes as Estimated by Means of Engel Curves.) Väestöntutkimuksen Vuosikirja VI, s. 99-108. Vammala 1960.

144. Stenbäck, Asser. Aktenskapskonflikterna i äktenskapsrådgivningen. Avioliitto ja Lääkäri 1961, 4, 109-113, 130.

\section{H. SIIRTOLAISUUS}

\section{International migration}

145. Aaltio, Tauri. Siirtosuomalaiset. Oma maa XI. s. 247-260. Porvoo 1962.

146. Forsberg, Karl-Erik. Emigrationsoch flyttningstendenser i svenska Österbotten. En intervjuundersökning med tre årsklasser landsbyggnadsungdomar. Bidrag till kännedom av Finlands natur och folk. Särtryck i serien Svenska befolkningsförbundets publikationer. Helsingfors 1964. $143 \mathrm{~s}$.

147. Forsberg, Karl-Erik. Kring svenskösterbottnisk emigration. Ekonomiska Samfundets Tidskrift 1963, 3, 171-179.

148. Forsberg, Karl-Erik. Synpunkter på finlandsvensk emigration. Kommunaltidningen 1961, 7, 161-166.

149. Hoglund, William A. Finnish immigrants in America 1880-1920. Madison 1960. $213 \mathrm{~s}$.

150. Häkli, Esko. Suomalaiset siirtolaiset Amerikassa. Suomalainen Suomi 1964, 3, 159-162.

151. Ingves, N. A. Emigrationen från svenska Österbotten i näringspolitisk belysning. Ekonomiska Samfundets Tidskrift 1963, 3, 180-191.

152. Koiranen, Vilho. Suomalaisten muuttoliike Ruotsiin. Den finska flyttningsrörelsen till Sverige. (The migration 
of Finns to Sweden.) Sosiaalinen Aikakauskirja 1964, 9-10, 349-359.

153. Mattila, Urho. Siirtolaisuus. Yhteiskuntatieteiden käsikirja II, s. 572-576. Keuruu 1964.

154. Mattila, Urho. Siirtolaisuutemme nykyisestä luonteesta Suomi-Seuralle vuonna 1959 tehtyjen tiedustelujen valossa. Väestöntutkimuksen Vuosikirja VII, s. 137 -144. Vammala 1962.

155. Pipping, K. ja Ida van HultenPipping. Den åländska ungdomens emigration. Ålands kulturstiftelse 3. Åbo 1961. $102 \mathrm{~s}$.

156. Savolainen, Pekka ja Erkki Kokkonen. Siirtolaisuus Lapin alueella vv. 1808-1930 seurakuntien kirkonkirjojen mukaan. Helsingin yliopiston sosiaalipolitiikan laitos. Tutkielmia 26. Turku 1964. $36 \mathrm{~s}$.

157. Toivonen, Anna-Leena. Etelä-Pohjanmaan valtamerentakainen siirtolaisuus 1867-1930. Yliop. väit. Seinäjoki 1963. $294 \mathrm{~s}$.

\section{MAASSAMUUTTO}

\section{Internal migration}

\section{Yleinen - General}

158. Geer, E. de. Migration in the Archipelago of southwestern Finland, during the last hundred years. Fennia 84. s. 67-90. Helsinki 1960.

159. Geer, E. de. Nettoflyttningsutbytet mellan Aland och Finland 1949-1953. Åländsk odling. Årsbok 1960. s. 100-118. Mariehamn 1960.

160. Jaatinen, Stig. The birthplace field of Helsinki according to the Census of 1950. Fennia 86. 5. s. 1-17. Helsinki 1962.

161. Koskimies, Y. S. Huomioita väestön liikkuvuudesta Jokioisten kappeliseurakunnassa vuosina 1678-1709. LounaisHämeen kotiseutu- ja museoyhdistyksen vuosikirja 1963, s. 46-51. Forssa 1963.

162. Lento, Reino. Suomen muuttoliikkeet. Oma maa XII. s. 191-203. Porvoo 1962.
163. Purola, Tapani. Internal migration in Finland in 1951-1955 and its regional variations. University of Helsinki, Institute of social policy. Reprint ser. B: 14 . Helsinki 1964. $8 \mathrm{~s}$.

164. Purola, Tapani. Maassamuuton vilkkaus. Tutkimus maassamuuton vilkkauden alueittaisista eroista ja niihin liittyvistä tekijöistä Suomessa v. 1951-1955. Sosiaalipoliittisen yhdistyksen tutkimuksia 11. Porvoo 1964. $172 \mathrm{~s}$.

165. Purola, Tapani. Maassamuuton voimakkuudesta ja suuntautumisesta Suomessa vuosina 1951-1955. (Summary: The Extent and Directions of Internal Migration in Finland during the Period 1951-1955.) Väestöntutkimuksen Vuosikirja VI, s. 46-59. Vammala 1960.

166. Siipi, Jouko. Siirtoväki. Yhteiskuntatieteiden käsikirja II, s. 581-586. Keuruu 1964.

\section{Kaupungit - maaseutu - Urban - rural}

167. Gustafsson, Frejvid. Helsingin vetovoima ympäristöalueen asukkaisiin. S. 115-144 teoksessa: Forsberg, K-E. ym. Helsingin seudun väestöllisestä kehityksestä ja siihen liittyvistä ongelmista. Valtakunnansuunnittelutoimiston julkaisusarja A: 13. Helsinki 1963.

168. Muuttuva maaseutu. Toim. Skyttä, Kyösti. Helsinki 1962, 137 s.

169. Nittymen, $H$. Nuorison maaltamuuton ongelmia Helsingissä. Lapsi ja Nuoriso 1960, 2, 48-51.

170. Niittynen, H. Väestökeskuksiin muuttavan nuorison ongelma. Maalaiskunta 1962, 22, 1030-1033.

171. Pohjola, Maj-Lis. Maaseudulta kaupunkiin. Ammatinvalinta 1962, 4, 6-8.

172. Raivio, Arvi. Maaltamuutosta vuosina 1956-60 tilaston valossa. Maalaiskunta 1962, 8, 346-348.

173. Raivio, Arvi. Ruotsin ja Suomen kaupunkien väestön kasvu. Suomen kunnallislehti 1963, 8, 493-494. - Städernas och köpingarnas befolknings utveckling i Sverige och Finland. Finsk Kommunaltidskrift 1963, 8, 493-494.

174. Raivio, Arvi, Urbanisaatiosta Suomessa viimeisten 50 vuoden aikana. Suomen Kunnallislehti 1962, 7, 329-331. 
175. Savonen, M. Maaseudun muuttotappiot. Maaseudun Työnantaja 1962, 3, 5-9.

176. Saxén, Ake. Tutkimus v. 1946 ja 1951 kaupunkiin muuttaneista naimattomista naisista. Undersökning rörande åren 1946 och 1951 inflyttade ogifta kvinnor. Tilastollisia kuukausitietoja Helsingistä 1962, 8, 217-238.

177. Typpö, S. A. Maamme kaupunkilaistumisesta. Maalaiskunta 1964, 14, 659 -663 .

178. Westermarck, Nils. Maaseudun muuttuvat kasvot. Sosiologia 1964, 3, 102110 .

\section{Asuttaminen - Settlement and resettlement}

179. Havukkala, Jaakko. Settlement and Economic Life in the District of the Lokka Reservoir in Finnish Lapland. Fennia 90, N:o 4. Lapin tutkimusseuran julkaisuja. Helsinki $1964.46 \mathrm{~s}$.

180. Ilvessalo, M. Suomen vuosien 1939 -40 ja 1941-44 sotien jälkeinen asutustoiminta metsätalouden kannalta. Metsäntutkimuslaitoksen julkaisuja 56:4. Helsinki $1963.184 \mathrm{~s}$.

181. Hertzen, Heikki von. Väestön kiihtyvä liikkuvuus ja yhdyskuntasuunnittelumme nykyongelmat. Valtakunnansuunnittelu 1964, 2, 7-8. (Myös Maalaiskuntalehdessä 1964.)

182. Jaatinen, Stig. Expansion and retreat of settlement in the southwestern archipelago of Finland. Fennia 1960, 84(1), 39-65.

183. Kulha, Keijo K. Asutustoiminta Keski-Suomessa 1945-1960 vuoden 1945 maanhankintalain nojalla. Keski-Suomen seutukaavatutkimuksia 4. Jyväskylä 1963. $159 \mathrm{~s}$.

184. Kähönen, Urho. Asutustoimintako lopetettava. Asutustoiminnan Aikakauskirja 1962, 2, 1-3.

185. Ohlson, B. Settlement and economic life in the parish of Enontekiö in northernmost Finland. Fennia 84. 2. s. 21-46, Helsinki 1960.

186. Palomäki, Mauri. Post war pioneering in Finland, with special reference to the role of the settlement areas. Fennia 84. 3. s. 43-68. Helsinki 1960.

187. Palomäki, Mauri. Suomen sodanjälkeisen asutustoiminnan alueellisia piirteitä. (Summary: Regional aspects of postwar land settlement in Finland.) Terra 1960, 4, 149-163.

188. Pihkala, K. U. Asutustoiminta. Oma maa VIII. s. 243-258. Porvoo 1960.

189. Sariola, Sakari. A colonization experiment in Bolivia. Rural Sociology 1960, 1, $76-90$

190. Soininen, Arvo. Pohjois-Savon asuttaminen keski- ja uuden ajan vaihteessa. Historiallisia tutkimuksia. Suomen historiallinen seura LVIII. Forssa 1961. $440 \mathrm{~s}$.

191. Varjo, Uuno. Lapin läänin asutuksen ja talouselämän kehitys toisen maailmansodan jälkeen. Lapin tutkimusseuran vuosikirja 3, s. 53-68. Kemi 1962.

192. Väisänen, P. O. Asutustoiminnan tarpeellisuudesta ja mahdollisuuksista Pohjois-Suomessa. Asutustoiminnan Aikakauskirja 1961, 2, 5-11.

193. Väisänen, P. O. Asutustoiminta Neuvosto-Aasiassa. Asutustoiminnan Aikakauskirja 1961, 1, 6-9.

\section{J. OMINAISUUDET (RAKENNE)}

\section{Characteristics}

\section{Demografiset ominaisuudet - Demo- graphic characteristics}

194. Alameri, Rolf. Muutamia havaintoja mies- ja naisenemmyydestä Suomen maalaiskunnissa vuosina 1910-1950. (Summary: Some Observations on the Preponderance of Males or Females in Finnish Rural Communes during the Period 1910-1950.) Väestöntutkimuksen Vuosikirja VI, s. 39-45. Vammala 1960.

195. Elfvengren, Elisabeth. Ruokakunnat vuonna 1960, I osa. Hushållen år 1960, I delen. (Summary: Households in 1960, part I.) Tilastollisia kuukausitietoja Helsingistä 1964, 6, 205-236. - II osa. 1964, 10, $377-400$. 
196. Hagan, Lyyli. Maan sairaanhoitajakunnan ikärakenne ja työvoimapula. Sairaanhoitajalehti 1963, 1, 6-8.

197. Hartman, Tor. Strukturförändringar i Finlands befolkning under 1950talet. Mercator 1962, 51-52, 904, 916.

198. Klövekorn, Martin. Die sprachliche Struktur Finnlands 1880-1950. Veränderungen im sprachlichen Charakter der finnland-swedischen Gebiete und deren bevölkerungs-, wirtschafts- und sozialgeographische Ursachen. Bidrag till kännedom av Finlands natur och folk. Finska Vetenskaps-Societeten. Heft 105. Helsingfors 1960,365 s. +10 karttaliitettä.

199. Linnamo, Jussi. Helsingin seudun väestörakenteen muuttuminen. Asuntoreformi 1964, 1, 16-21, 33.

200. Mäkelä, O. Analysis of some sex ratio data. Annals of Human Genetics 1962, 4, 333-334.

201. Renkonen, K. O. Decreasing sex ratio by birth order. Lancet 1963, 1, 60 .

202. Renkonen, K. O. The sex of live births born to aged women. Annales Medicinae Experimentalis et Biologiae Fenniae 1962, 40(4), 474-480.

203. Renkonen, K. O. et al. Factors affecting human sex ratio. Annales Medicinae Experimentalis et Biologiae Fenniae 1961, 39(2), 173-184.

204. Renkonen, K. O. et al. Factors affecting the human sex ratio. Nature 1962, 194, 308-309.

205. Strengell, Göran. Väestön sukupuoli- ja ikäryhmitys 31. 12. 1960. Väestönlaskennan ennakkotietoja. Befolkningens köns- och ålderfördelning den 31. 12. 1960. Förhandsuppgifter från folkräkningen. (Summary: Population by sex and age on 31 December 1960.) Tilastokatsauksia 1963, 9, 45-47.

206. Sweetser, Frank L. ja Paavo Piepponen. Nuoret ikäluokat Suomessa ja Yhdysvalloissa. (Summary: The Youthful Population of Finland and the United States.) Väestöntutkimuksen Vuosikirja VIII, s. 7-21. Vammala 1964.

207. Tuura, Antti. Väestönrakenteen kehitys 1950-luvulla. Maalaiskunta 1963, 4, $161-163$.
Taloudelliset ominaisuudet - Economic characteristics

208. Castrén, Pekka. Ammatissa toimivan väestön ennuste vuoteen 1990. (Summary: A projection of the economically active population of Finland to 1990.) Työmarkkinatutkimustoimisto, työvoimatutkimuksia I, Helsinki $1964.38 \mathrm{~s}$.

209. Elfvengren, Elisabeth. Ammattikoulutustaso Helsingissä v. 1960. Yrkesutbildningsnivån i Helsingfors år 1960 . (Summary: The level of vocational training in Helsinki in 1960.) Tilastollisia kuukausitietoja Helsingistä 1964, 5, 153-191.

210. Hautala, Heikki. Muuttuva elinkeinorakenteemme. Kaltio 1964, 2, 27-29.

211. Hustich, Ilmari. Suomen taloudellinen aluejako. Oma maa VIII. s. 226-240. Porvoo 1960. (Myös Terra 1960.)

212. Hyppölä, Jorma. Changes in the distribution of population between 1950 and 1960 by industry and industrial status. Bank of Finland Monthly Bulletin 1962, 11, 18-21.

213. Hyppölä, Jorma. Väestön elinkeinoja ammattiasemaryhmitys 31. 12. 1960. Väestönlaskennan ennakkotietoja. Befolkningens gruppering efter näringsgren och yrkesställning 31. 12. 1960. Förhandsuppgifter från folkräkningen. (Summary: Population by industry and industrial status on 31 December 1960. Preliminary census data.) Tilastokatsauksia 1962, 10, $45-48$.

214. Hyvärinen, Salme. Ammatissa toimivat naiset 1955. Yrkesverksamheten bland kvinnor 1955. (Summary: Women and employment in Helsinki, 1955.) Tilastollisia kuukausitietoja Helsingistä 1960, 11, 261-276.

215. Hyvärinen, Salme. Väestö kaupunginosittain elinkeinohaaran ja ammattiaseman mukaan 1955. Befolkningen stadsdelsvis efter näringsgren samt ställning i yrket 1955. (Summary: The distribution of the total population by city ward, branch of industry and oceupational status in 1955.) Tilastollisia kuukausitietoja Helsingistä 1960, 8, 197-200.

216. Hyvärinen, Salme. Väestön ryhmitys elinkeinon ja ammatin mukaan v. 1960. 
Befolkningens gruppering efter näringsgren och ställning i yrket år 1960 . (Summary: The population according to industry and occupational status in Helsinki, 1960.) Tilastollisia kuukausitietoja Helsingistä 1962, 12, 369-378.

217. Kiiskinen, Auvo. Elinkeinorakenteen kansainvälinen vertailu. Teollistuva yhteiskunta. Yhteiskunnallisen Korkeakoulun Vuosikirja VI. s. 82-100. Tampere 1962.

218. Kiiskinen, Auvo. Elinkeinot. Yhteiskuntatieteiden käsikirja I, s. 107-114. Keuruu 1963.

219. Kiiskinen, Auvo. Talousalue. Yhteiskuntatieteiden käsikirja II, s. 744-746. Keuruu 1964.

220. Knoellinger, F. C. E. Labor in Finland. Cambridge, Mass. 1960, London 1961. $300 \mathrm{~s}$.

221. Krisé, Maija. Teollisuuden työvoiman rakennemuutoksista Suomessa. Teollisuuslehti 1963, 1, 10-11.

222. Paukkunen, Leo. Metalliteollisuuden työvoiman rakenne ja kehitys. Taloudellinen tutkimuslaitos, Sarja A 5. s. 141161. Helsinki 1963.

223. Paukkunen, Leo. Työvoiman liikkuvuus Suomessa. (Summary: Labor mobility in Finland.) Taloudellinen tutkimuslaitos. Helsinki $1962.196 \mathrm{~s}$.

224. Raivio, Arvi. Kaupunki- ja kauppalaväestömme elinkeinojakautuma nykyisellään. Suomen Kunnallislehti 1962, 10, 526- 527 .

225. Raivio, Arvi. Suomen väestön elinkeinoryhmitys vuosina 1820-1870. (Summary: The Population of Finland in 1820-1870 by Industry.) Väestöntutkimuksen Vuosikirja VI, s. 29-38. Vammala 1960 .

226. Väestön elinkeinojakautumat vuosina 1950 ja 1960. (Population by industry in the years 1950 and 1960.) Valtakunnansuunnittelutoimiston julkaisusarja B: 7 . Helsinki 1964. 45 s.

\section{Sosiaaliset ominaisuudet - Social characteristics}

227. Elfvengren, Elisabeth. Pääkaupungin väestö sosiaaliryhmittäin vuonna 1960 . Huvudstadens befolkning enligt social- grupp år 1960. (Summary: The city population according to social groups in 1960.) Tilastollisia kuukausitietoja Helsingistä 1964, 1, 1-43,

228. Markkanen, Touko. Yhteiskuntaluokan teoriasta. Alkoholipoliittisen Tutkimuslaitoksen Tutkimusseloste N:o 6. Helsinki 1963. $29 \mathrm{~s}$.

229. Rauhala, Urho. Yhteiskuntaluokka. Yhteiskuntatieteiden käsikirja II, s. 1006 -1011. Keuruu 1964.

Muut ominaisuudet (kieli, rotu, biologiset seikat) - Other characteristics

230. Fougstedt, Gunnar. Finlandssvenskarnas befolkningsfråga. Läget i dag och framtidsperspektiv. Statsvetenskaplig Tidskrift 1963, 4, 400-414. (Eripainos:Meddelanden frain Ekonomisk-socialvetenskapliga Institutionen vid Svenska Handelshögskolan Nr 15 ja Svenska befolkningsförbundet i Finland publikationer Nr. 14.)

231. Fougstedt, Gunnar. Suomen ruotsalainen väestö. Oma maa XII, s. 162172. Porvoo 1962.

232. Vehmas, R. Suomen romaaniväestön ryhmäluonne ja akkulturoiminen. Turun yliopisto. Julkaisuja B-sarja 81. Turku 1961. $291 \mathrm{~s}$.

\section{K. VÄESTÖLLISTEN JA TALOU- DELLISTEN TEKIJÖIDEN VUOROVAIKUTUS}

\section{Demographic and economic interrelations}

\section{Työvoimaan kuuluminen - Labour force participation}

233. Ammatissa toimivat naiset 1955 . Yrkesverksamheten bland kvinnor 1955. Tilastollisia kuukausitietoja Helsingistä 1960, 11, 261-275.

234. Elfvengren, Elisabeth. Naimisissa olevien naisten työhönosallistuvuus. Väestöntutkimuksen Vuosikirja VIII, s. 114121. Vammala 1964.

235. Elfvengren, Elisabeth. Yrkesverksamheten i olika åldersgrupper. Geron 16, s. 19-30. Vammala 1964. 
236. Heurlin, Lauri O. af. Der Bevölkerungsüberschuss in der finnischen Landwirtschaft (The excess population in Finnish agriculture.) Weltwirtschaftliches Archiv (Hamburg) 1963, 90 (11), 101-114. 237. Pulkkinen, Terho. Nousukauden työttömyys ja nuori työvoima. Teollisuuslehti 1961, 11, 368-369.

238. Pulkkinen, Terho. Nuoren työvoiman asema Suomen työmarkkinoilla. Väestöntutkimuksen Vuosikirja VII, s. 127 -131. Vammala 1962.

239. Pulkkinen, Terho. Suurten ikäluokkien työllistämisongelma. Väestöntutkimuksen Vuosikirja VI, s. 120-125. Vammala 1960.

240. Pulkkinen, Terho. Työllisyysnäkymät 1960-luvulla. Pohjoismaiden Yhdyspankki, Unitas 1961, 4, 163-170.

241. Pulkkinen, Terho. Työttömyys ja työllisyyspolitiikka. Oma maa XII. s. 308 -317. Porvoo 1962.

242. Pulkkinen, Terho. Työttömyys yhteiskuntamme ongelmana. Liiketaloudellinen Aikakauskirja 1960, 11, 43-49.

243. Pulkkinen, Terho. Työvoiman ja työllisyyden kehitys. Osuuskassajärjestöjen taloudellinen katsaus 1964, 2, 47-51.

244. Pulkkinen, Terho. Työvoiman kausivaihtelut ja työllisyyspolitiikka. Erip. teoksesta sHeikki Waris ja 15 tohtorias. Porvoo 1961. $36 \mathrm{~s}$.

245. Quick, H. E. Työvoiman alueellisen liikkuvuuden edistäminen. Ammatinvalinta $1964,4,10-12,17$.

246. Ristimäki, Toini. Työintensiteetin kehitys Suomessa vuosina 1950-1961. KOP, Kuukausikatsaus 1961, 11-12, 1115.

247. Ristimäki, Toini. Åitien työvoimaan kuuluvuus ja lasten hoito äitien työssä ollessa. Väestöntutkimuksen Vuosikirja VII, s. 154-160. Vammala 1962.

248. Salas, Olavi. Työllisen työvoiman kehitys ja rakenne. Teollisuuslehti 1964, 6-7, 202-204.

249. Suomen akateeminen työvoima ja sen tarjonta. Taloudellinen tutkimuskeskus B: 14. s. 7-81. Helsinki 1964.

250. Viitala, Matti. Seinäjoen työttömän työvoiman rakenteesta. Kytösavut 9. s. 95-105, Seinäjoki 1962.
Taloudellinen kasvu - Economic growth

251. Kiiskinen, Auvo. Regional economic growth in Finland 1880-1952. Scandinavian Economic History Review 1961, 9(1), 83-104.

252. Kiiskinen, Auvo. Taloudellinen kasvu. Yhteiskuntatieteiden käsikirja II, s. 731-736. Keuruu 1964.

253. Miettunen, Martti, Väestörakenteen vaikutus kuntien talouteen. Maalaiskunta 1961, 6, 309-310.

254. Niitamo, Olavi E. ja Kaarlo Multimäki. Taloudellinen kasvu ja lahjakkuusreservit. (Summary: Economic Growth and Reserves of Ability.) Väestöntutkimuksen Vuosikirja VIII, s. 65-85. Vammala 1964.

\section{MUUT VUOROVAIKUTUS- SUHTEET}

\section{Other interrelations}

\section{Suuret ikäluokat ja koulukapasiteetti -} The large age-classes and educational facilities

255. Elfvengren, Elisabeth. De stora årsklassernas utbildningsmöjligheter. Mercator 1962, 43, 727-728.

256. Isokallio, Oiva. Ammatillinen peruskoulutus talousalueittain. Osuuskassajärjestön taloudellinen katsaus 1964, 3, $80-86$.

257. Isokallio, Oiva. Ammattikoulutustarve 1960-1965. Selvitys maamme työntekijäasteisesta ammattikoulutustarpeesta sekä sen jakaantumisesta ammateittain ja koulutusasteittain. Helsinki 1962. $68 \mathrm{~s}$. 258. Itälä, Jaakko. Uusia jatkokoulutusmuotoja n. 3000 ylioppilaalle. Avioliitto ja Lääkäri 1964, 2, 41-42.

259. Itälä, Jaakko. Ylioppilaiden uudet ammattikoulutusmuodot hahmottumassa. Valtakunnansuunnittelu 1963, 4, 7-8.

260. Niini, Aarno. Nuoren työvoiman ammattikasvatus. Väestöntutkimuksen Vuosikirja VII, s. 132-136. Vammala 1962 ,

261. Niint, Aarno ja Elisabeth Elfvengren. Nuorten koulunkäyntimahdollisuu- 
det ja työmarkkinoille tulo vuosina 1955 1965. (Training opportunities for young people in Finland and their entry into employment, 1955-1965.) Valtakunnansuunnittelutoimiston julkaisusarja A: 12. Helsinki 1962. 219 s. + 18 karttaa.

262. Vanhala, Kari. Ammattikoulutustilanteen kehittyminen ja lähivuosien näkymät. Valtakunnansuunnittelu 1962, 1, 2-3.

Väestönkehitys ja asunnontarve Population development and housing needs

263. Forsberg, Karl-Erik. Asunnontarve 1960-luvulla. Bostadsbehovet under 1960-talet. (Summary: The need for housing in the 1960's.) Tilastollisia kuukausitietoja Helsingistä 1964, 12, 437-451.

264. Hyvärinen, Salme. Alivuokralaisten, suurten ruokakuntien ja ns. asunnottomien asunnontarve v. 1961. Bostadsbehovet bland underhyresgäster, storhushåll och s.k. bostadslösa 1961. (Summary: Housing groups in Helsinki, 1961.) Tilastollisia kuukausitietoja Helsingistä 1961, 11, 357-372.

265. Kolari, Risto. Ennakkotietoja asunnontarpeesta Helsingissä 1960. Förhandsuppgifter beträffande bostadsbehovet i Helsingfors 1960. (Summary: The housing shortage in Helsinki 1960.) Tilastollisia kuukausitietoja Helsingistä 1961, 5, 165 180.

Väestönkehityksen vaikutus muilla aloilla - The influence of population development in other fields

266. Apple Sweetser, Dorrian. Urbanization and the Patrilineal Transmission of Farms in Finland. Acta Sociologica 1964, 4, 215-224.

267. Forsberg, Karl-Erik. Väestönmuutosten merkitys Helsingin kaupungin taloudenhoidossa 1940- ja 1950-luvuilla. S. 19-28 teoksessa: Forsberg, K-E. ym. Helsingin seudun väestöllisestä kehityksestä ja siihen liittyvistä ongelmista. Valtakunnansuunnittelutoimiston julkaisusarja A: 13. Helsinki 1963.
268. Fougstedt, Gunnar. Beräkningar rörande den framtida tillgången och efterfrågan på jurister i Finland. (Summary: The Future Supply of Lawyers in Finland and the Demand for Their Services.) Meddelanden från Ekonomisk-socialvetenskapliga Institutionen vid Svenska Handelshögskolan Nr 10. Helsingfors 1960. $24 \mathrm{~s}$.

269. Fougstedt, Gunnar. Lakimiesten tuleva kysyntä ja tarjonta Suomessa. Suomen Lakimiesliiton Tiedotuksia 4, Vammala 1960, 25 s. (Myös Ammatinvalintalehdessä 1960.)

270. Fougstedt, Gunnar. Problems of forecasting the future supply of persons with university training and the demand for their services. Meddelanden från Ekonomisk-socialvetenskapliga Institutionen vid Svenska Handelshögskolan. Nr. 11, Helsingfors 1962, 5 s. (Myös San Donato Milanese 1961 ja Bulletin de l' Institut International de statistique-lehdessä 1962.)

271. Fougstedt, Gunnar. Tarkistettu ekonomiennuste. (Summary: The Demand for and the Supply of Persons with the B. Sc. (Econ.) Degree, A New Prognosis.) Liiketaloudellinen Aikakauskirja 1962, 2, $75-89$.

272. Fougstedt, Gunnar ja Pentti Puumalainen. Agronomikunnan sodanjälkeinen kehitys sekä lähivuosien koulutustarve. Agronomien yhdistyksen julkaisu No 63. Forssa 1962. $18 \mathrm{~s}$.

273. Gosset, J. R. Medical demography and medical economies in Finland. World Medical Journal 1964, 11, 183-184.

274. Haavio-Mannila, Elina. Lääkärit tutkittavina. Helsingin yliopiston sosiologian laitoksen tutkimuksia 41, Helsinki 1964. $240 \mathrm{~s}$.

275. Haavio-Mannila, Elina. The structure of the medical profession in Finland. University of Helsinki, Institute of sociology, Publication 25. Helsinki 1964, 7 s. 276. Laaksonen, Oiva. Suomen liikeelämän johtajisto. Sen sosiaalinen liikkuvuus ja koulutus. Helsinki 1962, 294 s.

277. Pesonen, Niilo. Maamme lääkäritilanteesta ja toimenpiteistä sen parantamiseksi. Väestöntutkimuksen Vuosikirja VII, s. 123-126. Vammala 1962. 


\section{VÄESTÖPOLITIIKKA}

\section{Policies}

\section{Yleinen - General}

278. Kuusi, Pekka. 60-luvun sosiaalipolitiikka. Porvoo 1961. 373 s.

279. Nenonen, Ville. Perhekasvatuksesta. Lapsi ja Nuoriso $1963,1,4-8$.

280. Nieminen, Armas. Hyvinvointiyhteiskunnan ongelmia. Luotain 1962, 5, 12-17.

281. Purola, Tapani. Perhepolitiikka. Yhteiskuntatieteiden käsikirja I, s. 473477. Keuruu 1963.

282. Salo, Reino. Sosiaaliavustus. Yhteiskuntatieteiden käsikirja II, s. 594598. Keuruu 1964.

283. Social services in Finland. Social allowances. Ministry of Social Affairs. Helsinki 1964. $34 \mathrm{~s}$.

284. Sukselainen, V. J. Väestöpolitiikka. Yhteiskuntatieteiden käsikirja II, s. 993-996. Keuruu 1964.

285. Visuri, Elina. Mitä lapsen syntyminen maksaa? Väestöliitossa suoritettu selvitys. Avioliitto ja Lääkäri 1961, 1, 20-24. (Myös Sosiaalinen Aikakauskirja-lehdessä 1960, 11-12, 457-459.)

286. Visuri, Elina. Raskauden ja synnytyksen aiheuttamat kustannukset. (Summary: The Cost of Pregnancy and Childbirth in Finland.) Väestöntutkimuksen Vuosikirja VII, s. 101-120. Vammala 1962.

287. Väestöliitto. The Finnish population and family welfare league. L'union finlandaise pour la population. Helsinki $1960,35 \mathrm{~s}$.

288. Waris, Heikki. Suomalaisen yhteiskunnan sosiaalipolitiikka. Porvoo 1961. $315 \mathrm{~s}$.

\section{Perhekustannusten tasaus - The levelling-} out of the cost of the family maintenance

289. Hiisivaara-Mörck, Selma. Perhelisäjärjestelmä perhekustannusten tasaajana. Huoltaja 1963, 21, 668-670.

290. Kuusi, Pekka. Sosiaalimenot. Yhteiskuntatieteiden käsikirja II, s. 615618. Keuruu 1964.
291. Lindblom, Olavi. Laki lapsiperheiden asumistuesta ja sen sovellutus. Lagen angående bostadsbidrag för familjer med barn och dess tillämpning. Sosiaalinen Aikakauskirja 1963, 3-4, 97-111.

292. Lindgren, Jarl. Näkökohtia lapsilisän porrastamisesta. Sosiologia 1964, 1, $19-24$.

293. Lindgren, Jarl. Perhekustannusten tasauksen taloudellisesta merkityksestä. (Summary: The Economic Significance of the Equalization of Costs of Family Maintenance.) Väestöntutkimuksen Vuosikirja VIII, s. 86-102. Vammala 1964.

294. Peräläinen, Antero. Esimerkkejä lapsiperheiden kulutusmahdollisuuksien painumasta ja sen kattamisesta. Väestöntutkimuksen Vuosikirja VIII, s. 135-137. Vammala 1964.

295. Peräläinen, Antero. Lapsilisien ostoarvo 1951-1964. Huoltaja 1964, 21, $678-680$.

296. Peräläinen, Antero. Lapsilisäjärjestelmät eri maissa. Väestöntutkimuksen Vuosikirja VI, s. 139-152. Vammala 1960 .

297. Peräläinen, Antero. Lapsiperheiden asumistuki. Huoltaja 1963, 4, 109 110.

298. Peräläinen, Antero. Liikevaihtoverotuksen uudistuksen vaikutus lapsiperheiden kulutusmahdollisuuksiin ja rasituksen kompensoiminen. Lakimies ja Yhteiskunta 1963, 2, 6-7.

299. Peräläinen, Antero. Mahdollisuudet perhekustannusten tasausjärjestelmän tarkistamiseksi. Huoltaja 1964, 11-12, s. 355-359.

300. Peräläinen, Antero. Olisiko perhelisäjärjestelmää muutettava? Huoltaja 1963, 19, 591-596.

301. Peräläinen, Antero. Orpojen ja leskien eläketurvan aikaansaaminen Suomessa. Perhe-eläkkeet muissa maissa. Lakimies ja Yhteiskunta 1964, 4, 12-16. 302. Peräläinen, Antero. Perheasuntoavustukset Norjassa ja Tanskassa. Valtakunnansuunnittelu 1961, 1, 2-3. (Myös Asuntopolitiikka-lehdessä 1961.)

303. Per̃äläinen, Antero. Perhekustannusten tasauksen aste Suomessa. Väes- 
töntutkimuksen Vuosikirja VII, s. 145153. Vammala 1962.

304. Peräläinen, Antero. Perhekustannusten tasausjärjestelmän uudistamisen suuntaviivoja. Sosiaalityö 1963, 4, 108112, 124.

305. Peräläinen, Antero. Perhekustannusten tasausmenettelystä muissa maissa. Lakimies ja Yhteiskunta 1960, 3, 54-57. (Myös Avioliitto ja Lääkäri -lehdessä 1960.)

306. Peräläinen, Antero. Perheverotuksen uudistaminen. Lakimies ja Yhteiskunta 1963, 3, 15-19.

307. Peräläinen, Antero. Perheverotuksen uudistaminen veroluokkajärjestelmän pohjalta. Kansantaloudellinen Aikakauskirja 1963, 1, 43-57.

308. Peräläinen, Antero. Ruotsin perheenasuntoavustusjärjestelmä. Asuntopolitiikka 1960, 3, 3 .

309. Salomaa, Niilo. Erityislapsilisälain soveltamisesta. Huoltaja 1963, 18, 565572.

310. Salomaa, Niilo. Lapsiavustusjärjestelmämme kehitys. Huoltaja 1960, 6, 159163,167 .

311. Salomaa, Niilo. Luontoissuoritukset perhekustannusten tasauksessa. Huoltaja 1962, 24, 857-860.

312. Sarvas, Marjatta. Laki lapsiperheiden asumistuesta. Maalaiskunta 1962, 4, 143-145.

313. Sormo, Helge. Elatusavun ennakosta. Maalaiskunta 1963, 17, 723-729.

314. Waismaa, Usko. Erityislapsilisälaki. Lagen om specialbarnbidrag. (Act on Special Child Allowances.) Sosiaalinen Aikakauskirja 1961, 3-4, 121-125. (Myös Huoltaja- lehdessä 1961.)

315. Waismaa, Usko. Lapsilisän porrastus. Maalaiskunta 1962, 12, 525-526.

Toimenpiteet, jotka vaikuttavat syntyvyyteen - Measures affecting fertility

316. Bagh, K. v. Näkökohtia sterilisaatiokysymyksessä. Huoltaja, 1962, 22, 734-735.
317. Johansson, Carl-Johan. Gynekologens roll i äktenskapsrådgivningen. Avioliitto ja Lääkäri 1962, 1, 10-12.

318. Kauppila, O., P. Aro ja K. Soiva. Vuoden 1950 aborttilain vaikutus keskenmenoihin ja raskaudenkeskeytyksiin Tampereella. (Effect of the Abortion Act of 1950 on abortions and legal interruptions of pregnancy in the city of Tampere.) Duodecim 1962, 78, 946-953.

319. Kauppinen, Martti A. Äitiysneuvolatoiminnan kehityksestä ja tuloksista Helsingissä vuosina 1948-1959. Avioliitto ja Lääkäri 1961, 1, 7-11.

320. Lampen, Veikko. Väestöliiton avioliitto- ja sosiaalineuvoloiden toiminnasta. Kätilölehti 1960, 5, 215-216.

321. Lehto, Lauri. Väestöliiton Sosiaalineuvolan toiminnasta. Avioliitto ja Lääkäri 1960, 2, 47-50.

322. Olki, Mikko. Laillisista raskaudenkeskeytyksistä vv. 1953-1957. Avioliitto ja Lääkäri 1960, 1, 22-25.

323. Olki, Mikko. Laillisista raskaudenkeskeytyksistä vv. 1953-57. Väestöntutkimuksen Vuosikirja VIII, s. 122-134. Vammala 1964.

324. Olki, Mikko ja Erik Krokfors. Naistenklinikalla v. 1959 hoidetuista aborteista. Avioliitto ja Lääkäri 1960, 2, 53-57.

325. Paavilainen, Erkki. Aborttilain sosiaali-psykiatrisista indikaatioista. Avioliitto ja Lääkäri 1963, 3, 68-72.

326. Pitkänen, Heikki. Olemmeko hakoteillä myöskin laillisissa raskauden keskeyttämisissä? Avioliitto ja Lääkäri 1963, $2,44-46$.

327. Rauramo, Lauri ja Matti Grönroos. Huomioita sosiaalineuvolan potilaiden aborttimotivaatiosta. Avioliitto ja Lääkäri $1961,3,77-81$.

\section{Laatukysymys - Policy on quality}

328. Honkanen, Toini. Sterilisoimiskysymys ja lääkärin vastuu. Suomen Lääkärilehti 1962, 17, 1311-1319.

329. Kettunen, Inkeri. Sterilisoimiskysymykset vajaamielishuollossa. Huoltaja $1960,13-14,363-368$. 


\section{N. TUTKIMUKSEN JA ANA- LYYSIN MENETELMÄT}

Methods of research and analysis

330. Ajo, Reino. An approach to demographical system analysis. Economic Geography 1962, 38(4), 359-371.

331. Forsberg, Karl-Erik. Kansainvälistä kaupunkitilastoa. Internationell stadstatistik. Tilastollisia kuukausitietoja Helsingistä 1963, 6, 175-177.

332. Fougstedt, Gunnar. Ennuste. Yhteiskuntatieteiden käsikirja I. s. 124-125. Keuruu 1963.

333. Heikinheimo, Lauri. Jatkuva työvoimatutkimus. (The Current LabourForce Survey in Finland.) Väestöntutkimuksen Vuosikirja VI, s. 15-28. Vammala 1960 .

334. Heikinheimo, L., T. Pulkkinen ja $T$. Ristimäki. Jatkuva työvoimatutkimus. Fortlöpande arbetskraftsundersökning. (Summary: The Current LabourForce Survey in Finland.) Tilastokatsauksia 1961, 5, 44-53.

335. Hovinen, Esa. An investigation of mortality with IBM 650. Skandinavisk Aktuarietidskrift 1961, 1-2, 1-19.

336. Hyppölä, Jorma. Alueelliset jaot vuoden 1960 väestölaskennassa. (Summary: Regional divisions used at the Population Census 1960.) Terra 1962, 1, 35-41.

337. Hyppölä, Jorma. Automatisk databehandling vid 1960 års folkräkning i Finland. Statistisk Tidskrift 1963, 5, 364368 .

338. Hyppölä, Jorma ja Osmo Järvenpä̈. Taajamat ja niiden rajoittaminen vuoden 1960 väestönlaskennan yhteydessä. Tätorterna och deras avgränsning i samband med 1960 års folkräkning. (Summary: The non-administrative agglomerations and their circumscription with the 1960 population census.) Tilastokatsauksia 1961, 6, 45-54.

339. Härö, $A$. S. Suomen kuntien väestö v. 1960 pinta-aladiagrammana. (Summary: The Presentation of Population of Finland as Area Cartogram.) Terra 1963, 3, 245255.

340. Isotalo, Antti ja Aino Korpela. Kuolemansyytilaston luotettavuudesta ja kuolintodistusten perusteista. (Reliability of statistics on causes of death and the diagnostic basis of death certifications.) Suomen Lääkärilehti 1963, 18, 1537-1542.

341. Järvenpää, Osmo. Taajamatutkimus vuoden 1960 väestölaskennan yhteydessä. Maalaiskunta 1961, 14, 742-746.

342. Ristimäki, Toini. A current labour force survey in Finland. Bank of Finland Monthly Bulletin 1960, 34, 18-22.

343. Ristimäki, Toini. Jatkuva työvoimatutkimus. Fortlöpande arbetskraftundersökning. (Summary: Labour Force Sample Survey.) Tilastokatsauksia 1963, 7, 63-66 ja 1964, 5, 45-46.

\section{O. VÄESTÖNTUTKIMUKSEN ORGANISAATIO JA HALLINTO}

\section{Organization and administration}

344. Helsingin asunto- ja väestölaskenta 1955. Bostads- och folkräkningen i Helsingfors 1955. Erip. julkaisusta Tilastollisia kuukausitietoja Helsingistä. Helsinki 1962. $72 \mathrm{~s}$.

345. Hyppölä, Jorma. Vuoden 1960 väestölaskennan suunnitelmista. (Summary: The Plans for the 1960 Population Census in Finland.) Väestöntutkimuksen Vuosikirja VI, s. 7-14. Vammala 1960.

346. Hyppölä, Jorma. Väestön- ym. laskennat. Yhteiskuntatieteiden käsikirja II, s. 989-992. Keuruu 1964.

347. Ikkala, A. K. Maamme väestöluettelot. Oma maa VII. s. 169-179. Porvoo 1960 .

348. Laurila, Eino. Virallinen tilasto. Oma maa XII. s. 386-397. Porvoo 1962.

349. Liedes, Matti. Tilasto. Yhteiskuntatieteiden käsikirja II, s. 797-801. Keuruu 1964.

\section{P. KOKOUKSET JA KONFERENSSIT}

\section{Professional meetings and conferences}

350. Johansson, Carl-Johan. Nordiska Fertilitetsklubben. 2. kokous 28.1.1961 
Helsingissä. Avioliitto ja Lääkäri 1961, 2, 39-42.

351. Procopé, Berndt-Johan. Nordiska fertilitetsklubben. 3. kokous 27.1.1962 Tukholmassa. Avioliitto ja Lääkäri 1962, 3, 74-76.

352. Turpeinen, Kaisa. Kesän kansainväliset avioliitto- ja perheneuvontakongressit. Avioliitto ja Lääkäri 1962, 3, 77, 80.

353. Turpeinen, Kaisa. Syventymistä syntyvyyden säännöstelyyn tulppaanikenttien keskellä. International Planned Parenthood Federation'in kongressi Hollannissa 11-18 toukokuuta 1960. Avioliitto ja Lääkäri 1960, 3, 93-94.

\section{Q. KIRJALLISUUS Bibliographies}

354. Björklund, Maija. Kirj.arv.: Heikki Waris, Suomalaisen yhteiskunnan sosiaalipolitiikka (Porvoo 1961). Sosiaalityö 1961, 4, 135-136.

355. Elfvengren, Elisabeth. Kirj.arv.: Gertrude Bancroft, The american labor force: its growth and changing composition. A volume in the Census Monograph Series (New York 1958). Väestöntutkimuksen Vuosikirja VI, s. 158-160. Vammala 1960.

356. Elfvengren, Elisabeth. Kirj.arv.: Kvinnors liv och arbete. Kvinners liv og arbeid (Stockholm 1962). Mercator 1963, 9, 122-123, 128.

357. Forsberg, Karl-Erik. Kirj.arv.: Väestöntutkimuksen Vuosikirja VI (Vammala 1960). Ekonomiska samfundets Tidskirft 1961, 1, 57-58.

358. Fougstedt, Gunnar. Kirj.arv.: Martin Klövekorn, Die sprachliche Struktur Finnlands 1880-1950. Veränderungen im sprachlichen Charakter der finnlandswedischen Gebiete und deren bevölkerungswirtschafts- und sozialgeographische Ursachen (Helsinki 1960). Väestöntutkimuksen Vuosikirja VII, s. 165-166. Vammala 1962. (Nya Argus 1960, 15, 205-206.)

359. Heinilä, Kalevi. Kirj.arv.: Oiva Laaksonen, Suomen liike-elämän johtajisto (Porvoo 1962). Kansantaloudellinen Aikakauskirja 1963, 4, 293-296.
360. Kiiskinen, Auvo. Kirj.arv.: Ansley J. Coale \& Edgar M. Hoover, Population growth and economic development in lowincome countries (Princeton 1958). Väestöntutkimuksen Vuosikirja VII, s. 167170. Vammala 1962.

361. Korpela, Aino. Kirj.arv.: Satya Swaroop, Introduction to health statistics (Edinburgh and London 1960). Väestöntutkimuksen Vuosikirja VII, s. 170-171. Vammala 1962.

362. Lento, Reino. Kirj.arv.: Migration in Sweden, edited by David Hannerberg, Torsten Hägerstrand and Bruno Odeving (Lund 1957). Väestöntutkimuksen Vuosikirja VI, s. 160-163. Vammala 1960.

363. Lento, Reino. Kirj.arv.: Monikielinen väestötieteen sanakirja, Suomenkielinen laitos (Helsinki 1962). Väestöntutkimuksen Vuosikirja VII, s. 142-143. Vammala 1962.

364. Lindgren, Jarl. Kirj.arv.: Pierre de Bie, Budgets familiaux en belgique 1957-1958 (Louvain 1960). Väestöntutkimuksen Vuosikirja VII, s. 151-153. Vammala 1962.

365. Maamme korkeakouluissa vuosina 1950-1961 suoritettuja laudatur- ja lisensiaattitutkielmia väestöntutkimuksen alalta. Väestöntutkimuksen Vuosikirja VII, s. 173-179. Vammala 1962.

366. Majava, Altti. Kirj.arv.: Nordisk Byggnadskooperativ Organisation, Boligen i samfunnsökonomien (Helsinki 1960); Per Holm, Bostadsefterfrågan på 1960-talet (Stockholm 1959). Väestöntutkimuksen Vuosikirja VII, s. 171-173. Vammala 1962.

367. Majava, Altti. Kirj.arv.: Willian Petersen, Population (New York 1961). Väestöntutkimuksen Vuosikirja VII, s. 144 -145. Vammala 1962.

368. Mannio, Niilo A. Kirj.arv.: Heikki Waris, Suomalaisen yhteiskunnan sosiaalipolitiikka (Porvoo 1961). Suomalainen Suomi 1962, 9, 565-566.

369. Mickwitz, Gösta. Kirj.arv.: Leo Paukkunen, Työvoiman liikkuvuus Suomessa (Helsinki 1962). Ekonomiska Samfundets Tidskrift 1962, 2, 101-103. 
370. Modeen, Gunnar. Kirj.arv.: Pekka Kuusi, 60-luvun sosiaalipolitiikka (Porvoo 1961) ja Heikki Waris, Suomalaisen yhteiskunnan sosiaalipolitiikka (Porvoo 1961). Ekonomiska Samfundets Tidskrift1962, 1, 35-40.

371. Nieminen, Armas. Kirj.arv.: Heikki Waris, Suomalaisen yhteiskunnan sosiaalipolitiikka (Porvoo 1961). Sosiaalipolitiikan perusoppikirja. Huoltaja 1962, 1-2, 26-28. (Kansantaloudellinen Aikakauskirja 1962, 2, 179-181.)

372. Nieminen, Armas. Kirj.arv.: Pekka Kuusi, 60-luvun sosiaalipolitiikka (Porvoo 1961). Sosiaalityö $1961,4,132-133$.

373. Nieminen, Armas. Kirj.arv.: The study of population. An Inventory and Appraisal. Edited by Philip M. Hauser and Otis Dudley Duncan (Chigago 1959). Väestöntutkimuksen Vuosikirja VI, s. 163 -164. Vammala 1960.

374. Pensala, Väinö. Kirj.arv.: Pekka Kuusi, 60-luvun sosiaalipolitiikka (Porvoo 1961). Suomen Lääkärilehti 1961, 28, 1651-1654.

375. Piirainen, Veikko. Kirj.arv.: Heikki Waris, Suomalaisen yhteiskunnan sosiaalipolitiikka (Porvoo 1961). Huoltaja 1962, 1, 23-26.

376. Pirinen, Aulis. Kirj.arv.: Pekka Kuusi, 60-luvun sosiaalipolitiikka (Porvoo 1961). Sosiaalityö 1961, 4, 133-135.

377. Pulkkinen, Terho, Kirj.arv.: Leo Paukkunen, Työvoiman liikkuvuus Suomessa (Helsinki 1962). Kansantaloudellinen Aikakauskirja 1963, 1, 69-71.

378. Renvall, Pentti. Kirj.arv.: Arvo M. Soininen, Pohjois-Savon asuttaminen keski- ja uuden ajan vaihteessa (Forssa 1961). Historiallinen Aikakauskirja 1961, 2, 131-136.

379. Strömmer, Aarno. Kirj.arv.: George W. Barclay, Techniques of population analysis (New York 1958). Väestöntutkimuksen Vuosikirja VI, s. 164-165. Vammala 1960.

380. Strömmer, Aarno. Kirjallisuutta suomalaisen väestöntutkimuksen alalta vuosina 1953-1959. Literature of Finnish Population Research in 1953-1959. Väestöntutkimuksen Vuosikirja VI, s. 166185. Vammala 1960.
381. Tuomainen, Eero. Kirj.arv.: H. Correa and J. Tinbergen, Quantitative adaption of education to accelerated growth (Kyklos 4/1962). Väestöntutkimuksen Vuosikirja VII, s. 148-150. Vammala 1962.

382. Visuri, Elina. Kirj.arv.: Reuben Hill, I. Mayone Stycos and Kurt W. Back, The family and population control (Chapel Hill 1959) ja Lee Rainwater, And the poor get children (Chigago 1960). Väestöntutkimuksen Vuosikirja VII, s. 145 -148. Vammala 1962.

\section{R. VIRALLISET TILASTO- JULKAISUT}

\section{Official statistical publications}

383. Helsingin asunto- ja väestölaskenta 1955. Eripainos julkaisusta Tilastollisia kuukausitietoja Helsingistä. Bostads- och folkräkningen i Helsingfors 1955. Särtryck ur publikationen Statistiska månadsuppgifter för Helsingfors. IV. Helsinki $1960.58+\mathrm{X}$ s.

- 5. Helsinki 1962. $72 \mathrm{~s}$.

384. Helsingin kaupungin tilastollinen vuosikirja. Statistisk årsbok för Helsingfors stad. Statistical abstract of the city of Helsinki (Helsingfors).

1960. Helsinki 1960. 362 s.

- 1961. $355 \mathrm{~s}$.

- 1962. $350 \mathrm{~s}$.

- 1963. $370 \mathrm{~s}$.

- 1964. $375 \mathrm{~s}$.

385. Kuolemansyyt 1956-1957. Tauluja. Dödorsaker 1956-1957. Tabeller. Causes of death 1956-1957. Tables. SVT VI B 114. Helsinki 1960. $142 \mathrm{~s}$.

- 1958-1959. SVT VI B 115. 1961. $142 \mathrm{~s}$.

- 1960. SVT VI B 116. 1962. $74 \mathrm{~s}$.

- 1961. SVT VI B 117. 1963. $76 \mathrm{~s}$.

- 1962. SVT VI B 118. 1964. $76 \mathrm{~s}$.

386. Kuolleisuus- ja eloonjäämistauluja vuosilta 1956-1960. Dödlighets- och livslängdstabeller för åren 1956-60. Life tables 1956-60. SVT VI A 121 . Helsinki 1963. $31 \mathrm{~s}$.

387. Sosiaalihuoltotilaston vuosikirja. Socialvårdsstatistisk årsbok. Statistical yearbook of social welfare. SVT XXI B: 2. Helsinki $1960.117+18$ s. 
- 1959. SVT XXI B: $3.1961 .128+18 \mathrm{~s}$.

-1960 . SVT XXI B: $4.1962 .130+18 \mathrm{~s}$.

-1961 . SVT XXI B: $5.1963 .128+18 \mathrm{~s}$.

- 1962. SVT XXI B: $6.1964 .115+18 \mathrm{~s}$.

388. Suomen tilastollinen vuosikirja. Statistisk årsbok för Finland. Statistical yearbook of Finland. 1959. Helsinki 1960. $470 \mathrm{~s}$.

- 1960. 1961. $469 \mathrm{~s}$.

- 1961. 1962. $469 \mathrm{~s}$.

- 1962. $1963.477 \mathrm{~s}$.

- 1963. 1964. $496 \mathrm{~s}$.

389. Tampereen kaupungin tilastollinen vuosikirja 1959. Tampere 1960. $171 \mathrm{~s}$.

- 1960. 1961. $167 \mathrm{~s}$.

- 1961. 1962. $163 \mathrm{~s}$.

- 1962. $1963.160 \mathrm{~s}$.

- 1963. 1964. $171 \mathrm{~s}$.

390. Tilastokatsauksia. Julkaisija: Tilastollinen päätoimisto. Statistiska översikter. Utgivare: Statistiska centralbyrån. Bulletin of statistics. Published by the Central Statistical Office of Finland. 1960-1964. Helsinki.

391. Tilastollisia kuukausitietoja Helsingistä. Julkaisija: Helsingin kaupungin tilastotoimisto. Statistiska månadsuppgifter för Helsingfors. Utgivare Helsingfors stads statistiska byrå. 1960-1964. Helsinki.

392. Turun kaupungin tilastollinen vuosikirja. Statistisk årsbok för Åbo stad. 1958/1959. Turku 1960. $170 \mathrm{~s}$.

- 1960/1961. 1962. $179 \mathrm{~s}$.

- 1962/1963. 1964. $191 \mathrm{~s}$.

393. Vuoden 1960 väestölaskennan ennakkotietoja. Förhandsuppgifter från 1960 års folkräkning. Helsinki 1961. $152 \mathrm{~s}$.

394. Vuoden 1960 yleinen väestölaskenta. 1960 års allmänna folkräkning. 1960 Population Census, SVT VI C 103:

I. Asuntokanta. Bostadsbeståndet. Housing. Helsinki 1962. 164 s.

II. Väestön ikä, siviilisääty, pääkieli ym. Befolkningens ålder, civilstånd, huvudspråk mm. Population by age, marital status, main language, etc. Helsinki 1963. $134 \mathrm{~s}$.

III. Ammatissa toimivan väestön elinkeino ja ammattiasema. Förvärvsarbetande befolkning efter näringsgren och yrkeställning. Economically active population by industry and industrial status. Helsinki 1963. $73 \mathrm{~s}$.
IV. Väestön elinkeino ja ammattiasema. Befolkningen efter näringsgren och yrkeställning. Population by industry and industrial status. Helsinki 1963. 191 s.

V. Perheet. Familjer. Families. Helsinki 1964. $81 \mathrm{~s}$.

VI. Väestön sosioekonominen asema. Ammatissa toimivan väestön ikä. Työpaikan sijainti. Befolkningen efter socio-ekonomisk ställning. Den förvärvsarbetande befolkningen efter ålder. Arbetsplatsens belägenhet. Population by socio-economic status. Economically active population by age. Location of working place. Helsinki 1963. $77 \mathrm{~s}$.

VII. Ruokakunnat ja niiden asuminen. Hushållen och deras bostadsförhållanden. Households and their housing conditions. Helsinki 1963. 148 s.

VIII. Syntymäpaikka, koulusivistys, siirtoväki ym. Födelseort, skolbildning, förflyttad befolkning $\mathrm{mm}$. Population by birth-place and by education, displaced population, etc. Helsinki 1964. $63 \mathrm{~s}$.

IX. Ammatti ja ammattikoulutus. Yrke och yrkesutbildning. Occupation and vocational training. Helsinki 1964. 155 s.

X. Rakennuskanta. Byggnadsbeståndet. Buildings. Helsinki 1964. $320 \mathrm{~s}$.

395. Väestönmuutokset vuonna 1958. Befolkningsrörelsen år 1958. Vital statistics 1958. SVT VI A: 117. Helsinki 1960. $77 \mathrm{~s}$.

- 1959. SVT VI A 118 1961. $77 \mathrm{~s}$.

- 1960. SVT VI A 119 1962. 75 s.

- 1961. SVT VI A 120 1963. 80 s.

- 1962. SVT VI A 122 1964. $80 \mathrm{~s}$.

396. Yleinen terveyden- ja sairaanhoito. Allmän hälso- och sjukvård. Public Health and Medical Care. 1958. SVT XI: 61. Helsinki 1960. 89 s.

- 1959. SVT XI: 62. 1961. $94 \mathrm{~s}$.

- 1960. SVT XI: 63. 1962. 87 s.

— 1961. SVT XI: 64. 1964. 145 s.

397. Yleinen väestölaskenta Helsingissä vuonna 1960. Allmänna folkräkningen i Helsingfors år 1960. General Census of Population in Helsinki 1960. Helsingin kaupungin tilasto VII: 1 . Erikoistutkimukset. Specialundersökningar. Helsinki 1963. $173 \mathrm{~s}$.

— VII: 2. Helsinki 1964. 241 s. 
Aaltio, T. -145

Achté, K. A. - 91, 92, 94

Ahvenainen, E. K. -79

Ajo, R. $-35,50,330$

Alameri, R. - 194

Allardt, E. - 9, 10, 11

Antikainen, I. - 93

Apo, M. -94

Apple Sweetser, D. -266

Aro, P. -318

Bagh, K. v. -316

Bardy, A. -80

Björklund, M. -354

Bruun, K. -95

Castrén, P. -208

Elfvengren, E. - 12, 13, 36, 37, 195, 209, $227,234,235,255,261,355,356$

Eskola, A. - 123

Fogelberg, P. -38

Forsberg, K-E. - 1, 14, 15, 39, 52, 53, 146, $147,148,263,267,331,357$

Fougstedt, G. - 2, 6, 54, 230, 231, 268, 269, $270,271,272,332,358$

Geer, E. de - 158, 159

Gosset, J. R. - 273

Grönroos, M. - 327

Gustafsson, F. - 14, 15, 167

Haapaniemi, L. - 94

Haavio-Mannila, E. - 124, 125, 274, 275

Hagan, L. - 196

Hakama, M. - 96

Hakulinen, K. - 16

Hallman, N. -81

Hartman, T. $-17,40,41,42,55,75,107$, 197

Hautala, H. -210

Havukkala, J. - 179

Heikinheimo, L. - 333, 334

Heinilä, K. - 43, 126, 359

Heino, E. -99

Helle, R. -18

Hertzen, H. v. $-19,181$

Heurlin, L. af. -236

Hiisivaara-Mörck, S. -289

Hoglund, W. A. -149

Honkanen, T. -328

Hovinen, E. - 335

Hult, J. -44

Hultén-Pipping, I. van -155

Hustich, I. - 211
Hyppölä, J. - 6, 212, 213, 336, 337, 338, 345,346

Hyvärinen, S. $-14,15,20,214,215,216$, 264

Häkli, E. -150

Härö, A. S. -339

Ikkala, A. K. -347

Ilvessalo, M. -180

Immonen, E. - 45, 76, 97, 127

Ingves, N. A. -151

Isokallio, O. $-256,257$

Isotalo, A. - 98, 340

Itälä, J. - 258, 259

Jaatinen, S. $-21,22,160,182$

Jalavisto, E. -88

Joensuu, M. - 128

Johansson, C-J. - 115, 116, 317, 350

Jokipii, S. G. - 99

Jutikkala, E. - 46, 56

Järvenpää, O. - 338, 341

Järvinen, E. $-89,90,100$

Järvinen, P. A. - 115, 116

Kahanpää, K. H. -108

Kannisto, V. - 115, 116

Kasanen, A. - 82

Kauppila, O. - 318

Kauppinen, M. A. -319

Kauraniemi, T. - 117

Kauttu, K. -80

Kettunen, I. -329

Kiiskinen, A. - 3, 217, 218, 219, 251, 252, 360

Klemetti, L. - 101

Klövekorn, M. - 198

Knoellinger, F. C. E. -220

Koiranen, V. - 152

Kokkonen, E. - 156

Kolari, R. - 265

Korpela, A. - 102, 340, 361

Koskimies, Y. S. -161

Koura, E. -95

Krisé, M. - 221

Krokfors, E, - 103, 109, 324

Krokfors, G. - 103

Kulha, K. K. - 183

Kunnas, M. - 79

Kuusi, P. - 278, 290

Kähönen, U. - 184

Laakso, L. -86

Laaksonen, O. - 276 
Lampén, V. - 320

Lanu, K. E. - 129

Laurila, E. - 348

Lautkari, H. -4

Lehto, L. - 321

Lento, R. - 5, 58, 59, 162, 362, 363

Liedes, M. - 349

Lindblom, O. - 291

Lindgren, J. - 292, 293, 364

Linnamo, J. - 199

Louhivuori, P. -81

Lumio, J. S. -130

Majava, A. - 366, 367

Mannio, N. A. -368

Markkanen, T. -228

Mattila, A. - 104

Mattila, U. - 153, 154

Mazumdar, J. - 60

Mickwitz, G. -369

Miemois, K. -83

Miettunen, M. - 253

Modeen, G. -370

Multimäki, K. - 254

Mäkelä, O. - 200

Nenonen, V. - 279

Nieminen, A. - 110, 111, 131, 132, 133, 280, $371,372,373$

Nieminen, U. - 112, 118

Niini, A. $-260,261$

Niitamo, O. -254

Niittynen, H. - 169, 170

Nimkoff, M. F. - 134

Ohlson, B. -185

Olki, M. - 322, 323, 324

Paavilainen, E. - 325

Paljakka, P. - 130

Palmgren, K. $-47,48$

Palomäki, M. - 186, 187

Paukkunen, L. - 222, 223

Pensala, V. - 374

Peräläinen, A. - 294, 295, 296, 297, 298, 299, 300, 301, 302, 303, 304, 305, 306, 307, 308

Pesonen, N. - 277

Piepponen, P. - 49, 61, 62, 136, 137, 206

Piha, K. - 138

Pihkala, K. U. -188

Piirainen, V. -375

Pipping, K. - 24, 155

Pirinen, A. -376

Pitkänen, H. -326

Pohjola, M-L. - 171
Popham, R. E. -95

Procopé, B-J. - 351

Pulkkinen, T. - 237, 238, 239, 240, 241, 242, 243, 244, 334, 377

Purola, T. - 6, 25, 26, 63, 73, 163, 164, 165. 281

Puumalainen, P. - 17, 107, 139, 272

Quick, H. E. - 245

Raitasuo, K. - 140

Raivio, A. - 64, 65, 141, 142, 172, 173, 174, 224,225

Rauhala, U. - 229

Rauramo, L. - 82, 327

Renkonen, K. O. - 113, 201, 202, 203, 204

Renvall, P. -378

Ristimäki, T. $-246,247,334,342,343$

Räihä, C. E. - 84

Saarikivi, H. -27

Saarimaa, A. $-85,105$

Saarimaa, H. -105

Salas, O. - 248

Salo, R. - 282

Salomaa, N. - 309, 310, 311

Saramo, K. - 143

Sariola, S. - 189

Sarvas, M. - 312

Savolainen, P. -156

Savonen, M. - 28, 175

Saxén, A. - 14, 15, 66, 77, 96, 176

Seeley, J. R. - 95

Siipi, J. - 67, 166

Siirilä, S. - 29

Skyttä, K. - 168

Soininen, A. - 190

Soiva, K. - 318

Sormo, H. - 313

Stenbäck, A. - 144

Stolte Heiskanen, V. - 119

Strengell, G. - 205

Strömmer, A. - 6, 7, 14, 15, 30, 60, 66, 68, $69,70,379,380$

Sukselainen, V. J. -284

Sweetser, F. L. - 206

Takala, M. E. -86

Timonen, S. $-115,116$

Toivonen, A-L. -157

Tuomainen, E. -381

Turpeinen, K. - 352, 353

Tuura, A. - 26, 31, 32, 33, 71, 72, 73, 207

Typpö, S. A. -177

Vanhala, K. - 262 